Case Report

\title{
Progressive Ovarian Cancer with Trocar Site Metastases Resulted from Inadequate Laparoscopy
}

\author{
Karsinoma Ovarium Progresif dengan Metastasis pada Skar Insisi Trokar \\ dengan Riwayat Laparoskopi Inadekuat
}

\author{
Sigit Purbadi, Ina Damayanti \\ Gyncecology Oncology Division \\ Department of Obstetrics and Gynecology \\ Faculty of Medicine University of Indonesia/ \\ Dr. Cipto Mangunkusumo General Hospital \\ Jakarta
}

\begin{abstract}
Objective: Discuss the complications of laparoscopic ovarian cystic neoplasms.

Method: Case report. A-52 year old female with 2 parities, complained of a lump at anterior abdominal wall during chemotherapy for clear cell ovarian adenocarcinoma after total hysterectomy and bilateral salphingooophorectomy by laparoscopy. The indication was suspected ovarian cancer from solid parts found during ultrasound and CA125 level 169. During previous laparoscopy, the cyst was ruptured, left in abdominal cavity with high $\mathrm{CO}_{2}$ pressure for five hours and retrieved without a bag. The frozen section examination of the cyst wall were diagnosed as endometriosis. The physician assured her that the lump was only scar and did not need further evaluation. CA125 level was 557 IU after chemotherapy. PET scan confirmed a $2 \mathrm{~cm}$-diameter mass superior to peritoneum and multiple implants intra abdominally.

Result: A debulking laparotomy was done. Omental cake was found with one part adhered to the right previous trocar insertion site. It was connected to tumor implant size $3 \times 4 \mathrm{~cm}$ until fat tissue of abdomen wall. Another implant was also found at left paracolical area.

Conclusion: Laparoscopy offers advantages such as less bleeding, better visualisation, and enhanced recovery. Some controversies exist in cases with suspicion of malignancy. Pneumoperitoneum might cause seeding of tumor cells. This could be prevented by using low pressure, avoidance of exsuflation of gas through trocar opening, or by using bags to retrieve operative specimens. Preoperative evaluation of clinical findings, ultrasound, and tumor markers are important to prevent improper surgical management.

[Indones J Obstet Gynecol 2014; 2: 110-113]
\end{abstract}

Keywords: complication, laparoscopy, metastases, ovarian cancer, trocar site.

\begin{abstract}
Abstrak
Tujuan: Membahas komplikasi laparoskopi neoplasma ovarium kistik.

Metode: Laporan kasus. Seorang perempuan 52 tahun dengan riwayat paritas dua, mengeluhkan massa pada abdomen saat menerima kemoterapi adenokarsinoma ovarium tipe clear cell setelah menjalani laparoskopi histerektomi total salfingooforektomi bilateral. Indikasi laparoskopi tersebut adalah NOK suspek ganas berdasarkan temua USG dan CA125 level 169. Saat laparoskopi, kista ruptur dengan mengeluarkan cairan coklat, terpapar lama intraabdomen selama lima jam dengan keadaan pneumoperitoneum dan massa kista dikeluarkan tanpa kantung. Hasil potong beku menunjukkan endometriosis. CA125 setelah kemoterapi adalah 557 IU. Pemeriksaan PET scan menunjukkan massa abdomen tersebut adalah metastasis disertai gambaran implan multipel intraabdomen.
\end{abstract}

Hasil: Pasien menjalani laparotomi debulking Omental cake ditemukan dengan adhesi pada tempat insersi trokar sebelumnya yang tersambung dengan implan tumor $3 \times 4 \mathrm{~cm}$. Ditemukan pula implan lain pada daerah parakolika kiri.

Kesimpulan: Keuntungan laparoskopi menjadikan alternatifmenjanjikan untuk tatalaksana bedah massa adneksa. Namun, pada kecurigaan keganasan hendaknya dilakukan antisipasi untuk mencegah metastasis akibat pneumoperitoneum seperti penggunaan tekanan intraabdomen rendah, mencegah eksuflasi melalui luka trokar, atau menggunakan kantung untuk mencegah spillage dan mengeluarkan spesimen. Evaluasi preoperatif sangat penting untuk menentukan metode pembedahan yang sesuai.

[Maj Obstet Ginekol Indones 2014; 2: 110-113]

Kata kunci: karsinoma ovarium, komplikasi, laparoskopi, luka trokar, metastasis

Correspondence: Ina Damayanti. Department of Obstetrics and Gynecology. Faculty of Medicine University of Indonesia/ Dr. Cipto Mangunkusumo General Hospital. Jakarta. Mobile: 08567982846. Email: gundam2541@gmail.com

\section{INTRODUCTION}

Laparoscopic approach has been a revolutionary technique in gynecology. The technique is well known in reducing length of stay, enhancing patient's recovery, and reducing the expenses. Laparoscopic management of gynecologic cancer is controversial somehow. Evaluation of lymph nodes in advanced cervical cancer, radical hysterectomy in early cervical cancer, endometrial cancer, and early ovarian cancer had been done by laparoscopy. The risk for intraperitoneal spreading of the malignancy was believed to rise by the procedure. 
Even so, studies had analyzed that risk of dissemination and metastases at trocar site are mainly related to manipulations, spill of cancerous tissue intraoperatively, or unprotected specimen removal. ${ }^{1}$ These factors should be remembered by the surgeon during the procedure.

When a suspicious of malignancy was found intraoperatively during a laparoscopy, and measures to prevent metastases can not be taken, it is optional to immediately convert the procedure. However if the gynecologic oncologist to perform immediate conversion to laparotomy is not present, the longer interval time between first laparoscopy and definitive surgeries will increase the rate of having advanced disease. ${ }^{2}$ The circumstances might occur in cases of unsuspected malignancy of the ovary. Although preoperative assessment of mass has carefully considered postmenopausal status, highly elevated CA-125 level, CT scan or ultrasound findings, the chance of unexpected ovarian malignancy could be as high as $0.9 \%$ in premenopausal patients and $3.0 \%$ in postmenopausal patients. ${ }^{3-5}$

\section{Case}

A-52-years-old lady P2, had a laparoscopic total hysterectomy and bilateral salphingooophorectomy for a suspected ovarian cancer from solid parts found during ultrasound and CA125 level 169. Intraoperatively right ovary was enlarged cystically sized approximately $15 \mathrm{~cm}$. Uterus and left ovary were normal. No free fluid was observed. No nodules were found at peritoneum. The cyst was multilobulated and relatively not adhered to surrounding organs. Cyst was ruptured iatrogenically with chocolate thick fluid coming out of it. Eventually solid part was revealed by cutting the cyst. Frozen section taken from $20 \times 20 \times 2 \mathrm{~mm}$ cyst wall revealed benign endometriosis. Regardless, total hysterectomy and bilateral salphingooophorectomy was performed. The rest of mass were extracted without endobag. The final paraffin block findings were normal uterus with clear cell adenocarcinoma arise directly from ovarian surface epithelium. She was then scheduled to receive six cycles chemotherapy using carboplatin $300 \mathrm{mg}$ and paclitaxel $200 \mathrm{mg}$ regiments. During chemotherapy she felt a lump appeared at the previous trocar site scar, but was told to be normal. PET scan examination after chemotherapy confirmed a $2 \mathrm{~cm}$-mass in diameter superior to peritoneum and multiple implants sprea- ded intraabdominally as a progression of the cancer. CA125 level rises to 557 .

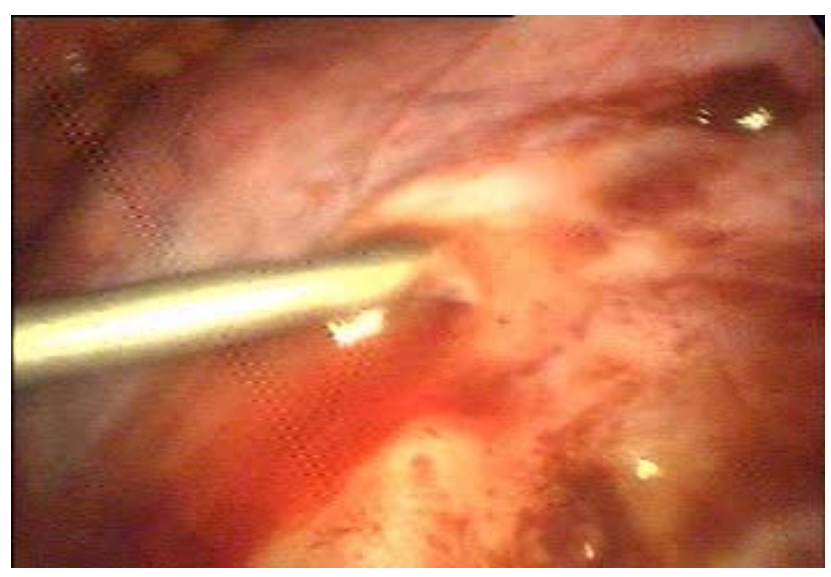

Figure 1. Iatrogenic puncture of the cyst.

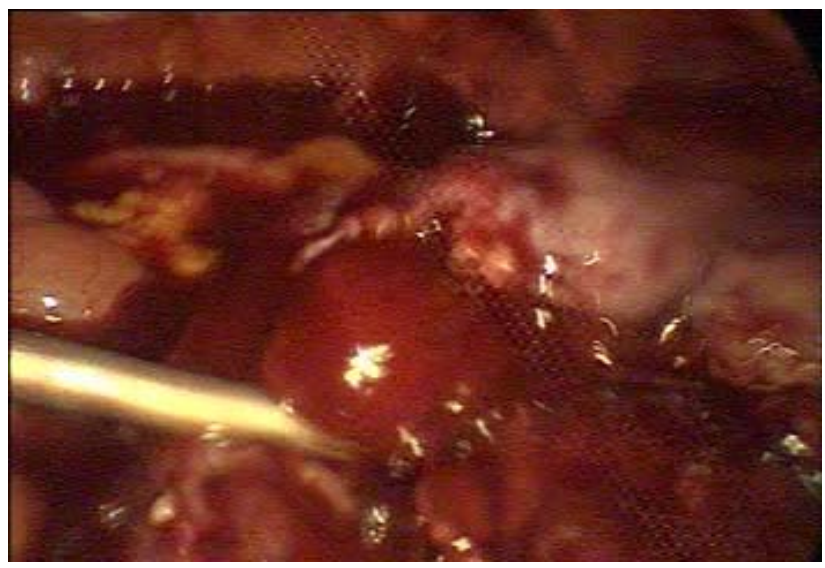

Figure 2. Solid part of the cyst taken for frozen section.

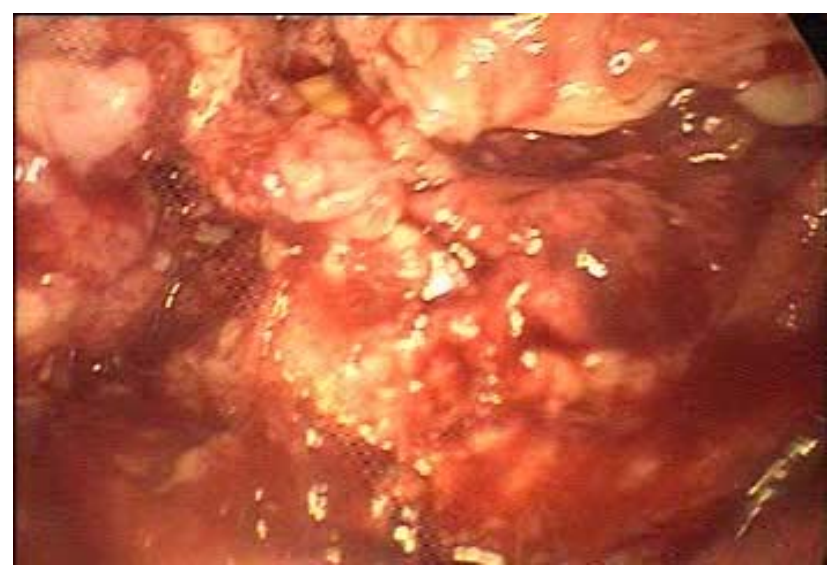

Figure 3. Solid part of the cyst suspicious of malignancy. 


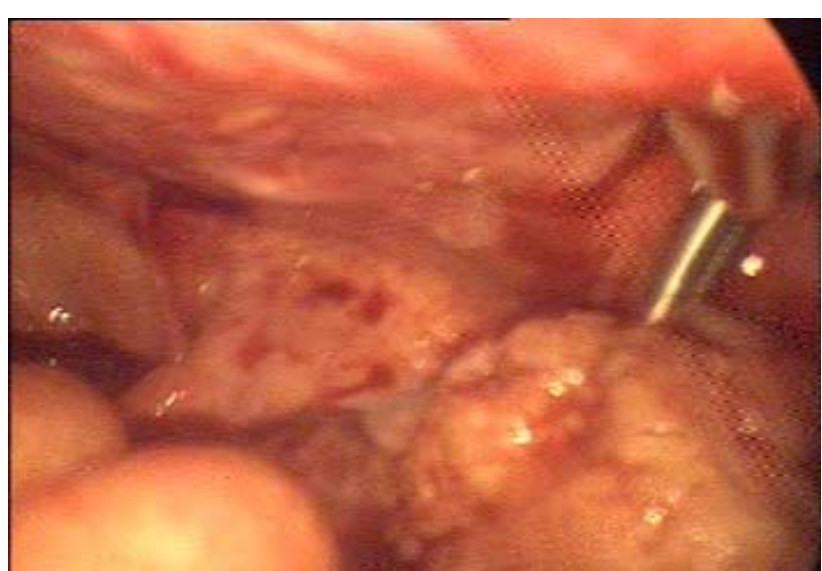

Figure 4. Tumor extraction without endobag.

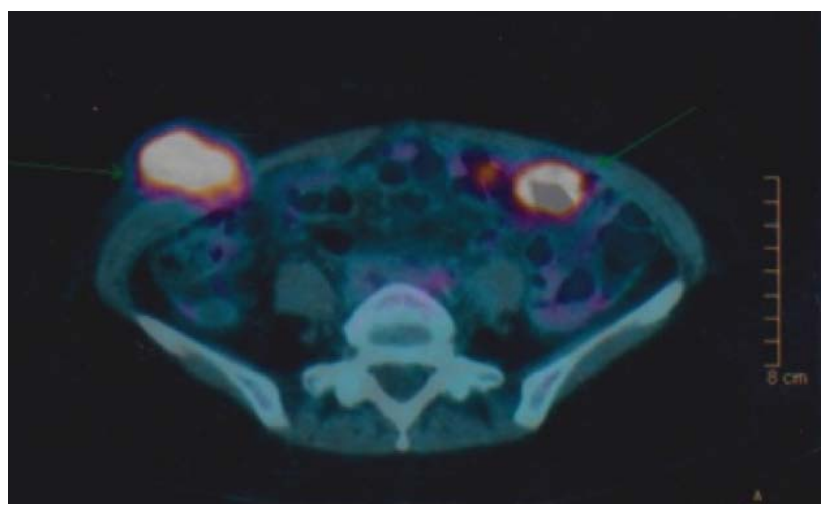

Figure 5. PET Scan result after chemotherapy.

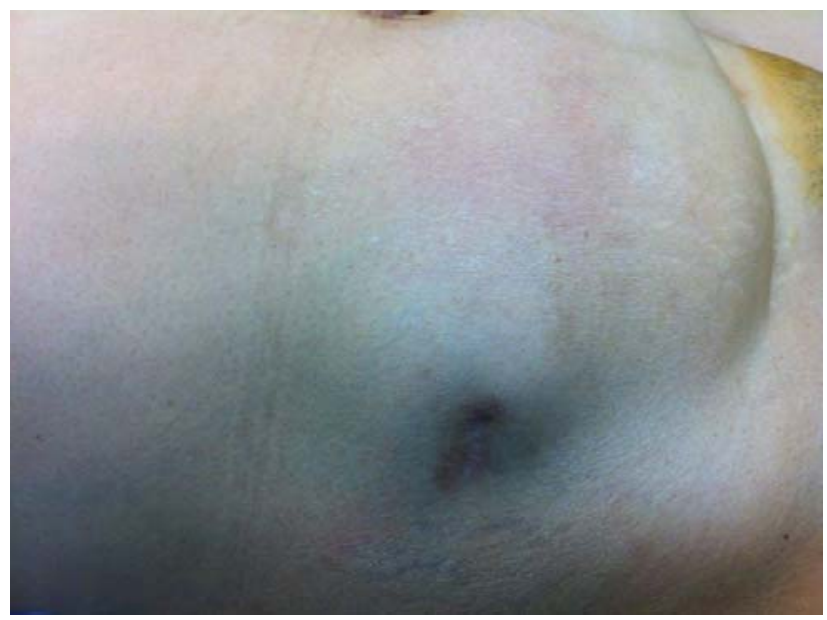

Figure 6. Trocar site metastases.

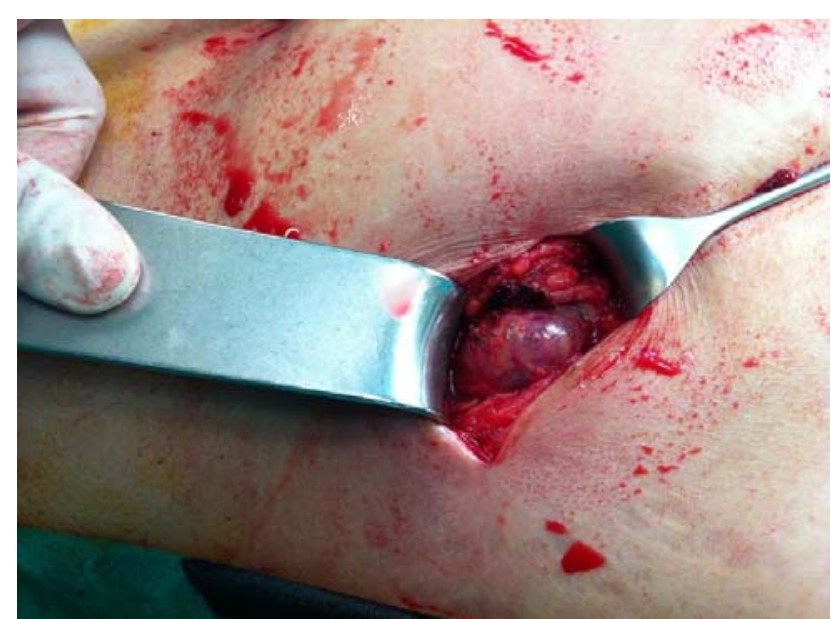

Figure 7. Metastases mass before excision.

\section{Case Management}

A debulking laparotomy was done. During surgery we found omental cake, with part of the omentum adhered to the right previous trocar insertion site. The omentum was connected to tumor implant size $3 \times 4 \mathrm{~cm}$ that penetrated until fat tissue of abdomen wall. Afterward, the debulking was continued by excising implant found at left paracolical area. Omentectomy was performed. The histopathology examination revealed clear cell adenocarcinoma metastases.

Currently patient is in good condition and receiving second line chemotherapy with oxaliplatin, gemcitabin (day 1-day 8), and bevacizumab.

\section{DISCUSSION}

Appropriate patient selection and correct intraoperative management are the key points in laparoscopic approach to ovarian cancer. Patient should be informed about possibility of conversion to laparotomy or the need for second surgery because incomplete staging, as well as risk of spillage, tumor cell dissemination, and trocar site metastases. Compared to cervical and endometrial cancer, laparoscopy in ovarian cancer carries some risks of progression of disease. But this option is debatable. Intraperitoneal spreading and trocar site metastases happened because of long exposure of high $\mathrm{CO}_{2}$ pressure and the disposal of cyst not by endobag. Other important aspect is how to perform appropriate sampling for frozen section. When all these measures were applied, under management of early cancer would not occur. However, there is 
still a chance of unexpected ovarian malignancy could be as high as $0.9 \%$ in premenopausal patients and $3.0 \%$ in postmenopausal patients in laparoscopy of ovarian cyst.

Trocar site metastases could occur because of the passage of tumor specimens at the port sites. Carbon dioxide"s "chimney" effect floats tumor cells through the port wounds during the release of pneumoperitoneum. Other theories mentioned were the pre-existing ascites, the depressed immunity secondary to surgical stress, direct extension of the cancer to the port site, or the contaminated instruments causing metastases. ${ }^{6,7}$ The use of endobag is mandatory to prevent tumor contact with the port site. Zero rate trocar site metastases in a study of 24 laparoscopy for early stage ovarian cancer with endobag has confirmed its importance. ${ }^{6}$ In a study of 3,138 adnexal mass laparoscopic patients in which 41 patients(1.31\%) were histologically proven to have a borderline tumor and $7(0.22 \%)$ patients were diagnosed with ovarian carcinoma, no trocar site metastases occur when strict rule of using endobags is applied. ${ }^{8}$ Minilaparotomy could be done to evacuate larger mass. Other proposed technique to prevent dissemination of cancer cell is by doing salphyngooophorectomy including the posterior leaf of broad ligament extending to pararectal peritoneal sheath in order for the ligament to prevent spillage during evacuation as has been studied by Perutelli et al. ${ }^{9}$

When histological confirmation of ovarian cancer was made after first surgery, chemotherapy or a secondary surgery must be perform for appropriate staging and debulking. Tozzi et al. concluded that laparoscopic treatment is safe for early ovarian cancer or adnexal mass that turned out to be an ovarian cancer, with 11 (45.8\%) out of 24 patients underwent completion of staging after a mean of 12 days or received adjuvant chemotherapy after a median time of 7 days. No trocar site metastases was found. After a median follow-up of 46 months, disease-free survival was $91.6 \%{ }^{6}$

In this case, the proper preoperative assessment has been done. Even so, during laparoscopy inappropriate evacuation of the mass without endobag perpetuated the dissemination of tumor cells. Furthermore, the benign result coming from frozen section masked the operator judgement for the correct management. This happened as a result of improper sampling of the mass. The operator should have taken the solid part for evaluation instead of the cyst wall. In the other hand, clear cell carcinoma is known to have poor prognosis because of the platinum-resistent characteristics and its poor response to chemotherapy. These may contribute to the rapid progression in this patient. We could learn that from this lesson, applying the same standard management in every laparoscopic surgery of adnexal mass is a must. Patient should be informed of the worst possibilities from a surgery that she must go through. Hence, any follow up procedures that must be taken could be consider as a comprehensive management and not a malpractice event.

\section{REFERENCES}

1. Belval CC, Barranger E, Dubernard G, Touboul E, Houry S, Darai E. Peritoneal carcinomatosis after laparoscopic radical hysterectomy for early-stage cervical adenocarcinoma. Gynecol Oncol. 2006; 102: 580-2.

2. Lehner RWR, Heinzl H. Influence of delayed staging laparotomy after laparoscopic removal of ovarian masses later found malignant. Obstet Gynecol. 1998; 92: 967-71.

3. Liu CS, Nagarsheth NP, Nezhat FR. Laparoscopy and Ovarian Cancer: A Paradigm Change in the Management of Ovarian Cancer? J Minimally Invasive Gynecol. 2009; 16: 250-62.

4. Frumovitz M, Ramirez PT, Greer M, Gregurich MA, Wolf J, Bodurk DC, et al. Laparoscopic training and practice in gynecologic oncology among Society of Gynecologic Oncologists members and fellows-in-training. Gynecol Oncol. 2004; 94: 746-53.

5. Muzii L, Angioli R, Zullo M, Panici PB. The unexpected ovarian malignancy found during operative laparoscopy: Incidence, management, and implications for prognosis. J Minimally Invasive Gynecol. 2005; 12: 81-9.

6. Tozzi R, Kohler C, Ferrara A, Schneider A. Laparoscopic treatment of early ovarian cancer: surgical and survival outcomes. Gynecol Oncol. 2004; 93: 199-203.

7. Carlson NL, Krivak TC, William E. Winter I, Macri CI. Port Site Metastasis of Ovarian Carcinoma Remote from Laparoscopic Surgery for Benign Disease. Gynecol Oncol. 2002; 85: 529-31.

8. Brosi N, Deckardt R. Endoscopic surgery in patients with borderline tumor of the ovary: A follow-up study of thirtyfive patients. J Minimally Invasive Gynecol. 2007; 14: 606-9.

9. Perutelli A, Garibaldi S, Basile S, Baldacci C, Gargini A, Domenici L, et al. Laparoscopic Adnexectomy of Suspect Ovarian Masses: Surgical Technique Used To Avert Spillage. J Minimally Invasive Gynecol 2011; 18: 372-7. 